\title{
Progress in solid electrochemical gas sensors based on NASICON and oxide electrodes
}

\author{
Xishuang Liang ${ }^{1}$, Biao Wang ${ }^{2}$, Houbo Zhang ${ }^{1}$, Quan Diao ${ }^{1}$, Baofu Quan ${ }^{1}$ and Geyu Lu ${ }^{1 *}$ \\ 1 State Key Laboratory on Integrated Optoelectronics, College of Electronic Science and Engineering, \\ Jilin University, 2699 Qianjin Street, Changchun 130012, China; \\ Corresponding e-mail address: lugy@jlu.edu.cn \\ 2 Changchun Institute of Optics, Fine Mechanics and Physics, CAS, 3888 Dong Nanhu Road, \\ Changchun 130033, China.
}

\begin{abstract}
The mixed-potential type NASICON-based sensor attached with an oxide electrode is generally used at intermediate temperatures and more suitable for monitoring the harmful and toxic gases in the atmospheric environment. This presentation focuses on the exploration of new oxide electrode materials and the design of new sensor structure for increasing the sensing performance of the sensor based on NASICON and oxide electrode.
\end{abstract}

Key words: NASICON, gas sensor, oxide electrode, mixed potential

\section{Introduction}

With the increasing of world's population and the acceleration of the industrialization process, lots of harmful gases $\left(\mathrm{CO}_{2}, \mathrm{SO}_{x}, \mathrm{NO}_{x}, \mathrm{H}_{2} \mathrm{~S}, \mathrm{NH}_{3}\right.$, $\mathrm{CO}$ and so on) from the power generation, heat supplying, metallurgy, chemical production and motor vehicle lead to the greenhouse effect, acid rain, photochemical smog and other environmental disasters. Therefore, the highperformance environment gas sensors have been urgently desired for detecting and monitoring these hazardous gases. Up to now, various kinds of gas sensors based on semiconductor oxides [1], organic thin films [2] and solid electrolytes [3] have been developed. Among them, the solid electrolyte type sensors exhibit excellent sensing performances, such as high sensitivity, rapid response kinetics, outstanding selectivity and reproducibility. For the solid electrolyte sensors, most researches focused on the sensors based on yttria stablized zirconia (YSZ) and sodium super ionic conductor (NASICON). In general, the YSZbased sensor was operated at high temperature $\left(600-800^{\circ} \mathrm{C}\right)$, so it seems to be inappropriate for detecting the gases in atmospheric environment because of its low sensitivity as well as high power consumption. Contrary to the YSZ-based sensors, the mixed potential type sensors based on NASICON are generally operated at the intermediate temperatures $\left(300-500^{\circ} \mathrm{C}\right)$, so they are more suitable for detecting the hazardous gases in the atmospheric environment. According to the sensing mechanism, the NASICON-based gas sensors are mainly divided into three types: the currenttype, the equilibrium-potential-type and mixedpotential-type. N. Miura et al. developed the current $\mathrm{NO}_{2}$ sensor based on NASICON and $\mathrm{NaNO}_{2}$ electrode. The sensor has good linearity within the range of $10 \mathrm{ppb}-1 \mathrm{ppm}$ concentration at $150^{\circ} \mathrm{C}$ [4]. As for the equilibrium potential type sensors, N. Yamazoe et al systematically researched the $\mathrm{CO}_{2}$ sensors using a series of composite carbonate, e.g. $\mathrm{CO}_{2}$ sensors with good moisture resistance have been fabricated by using $\mathrm{Na}_{2} \mathrm{CO}_{3}-\mathrm{BaCO}_{3}$ and $\mathrm{Li}_{2} \mathrm{CO}_{3}-\mathrm{BaCO}_{3}$ as the auxiliary electrode [5, 6]. S. Choi et al. reported $\mathrm{SO}_{2}$ sensor using $\mathrm{Na}_{2} \mathrm{SO}_{4}$ and $\mathrm{Na}_{2} \mathrm{SO}_{4}-\mathrm{BaSO}_{4}$ as auxiliary electrodes [7], which showed excellent stability. K. Obata et al. developed the equilibrium-potential-type $\mathrm{NO}_{2}$ sensor with ITO and $\mathrm{NaNO}_{2}-\mathrm{Li}_{2} \mathrm{CO}_{3}$ as the auxiliary electrode, which had low detecting limit (about 2ppm) and an excellent moisture resistance [8]. For above two types of sensors, the long-time stability and moisture resistance need further be improved, due to the hygroscopicity of the oxysalt auxiliary electrode as well as the interface reaction between the oxysalt and NASICON. Unlike these two types of sensors, the mixed-potential-type sensor based on NASICON uses an oxide as a sensing electrode which has good moisture resistance and not directly involved in the electrode reaction (electrode catalyst), so it has been a hot research topic in recent years. Y. Shimizu et al developed a $\mathrm{CO}_{2}$ sensor with $\mathrm{NdCoO}_{3}$ and $\mathrm{La}_{0.8} \mathrm{Ba}_{0.2} \mathrm{CoO}_{3}$ as sensing 
electrode, which improved the stability and moisture resistance, but the sensitivity need to be improved [9]. They also developed mixedpotential-type $\mathrm{NO}_{\mathrm{x}}$ sensor with $\mathrm{Pb}_{2} \mathrm{Ru}_{1.9} \mathrm{~V}_{0.1} \mathrm{O}_{7-\mathrm{z}}$ as sensing electrode. However, the systematic investigation about the NASICON-based mixed potential type sensor has been scarcely reported.

This paper provides an overview and mainly discusses the mixed-potential-type gas sensors based on NASICON solid electrolyte and metal oxide electrodes developed by our group.

\section{Methods}

The NASICON was synthesized with $\mathrm{ZrO}\left(\mathrm{NO}_{3}\right)_{2}$, $\mathrm{NaNO}_{3}$, $\left(\mathrm{NH}_{4}\right)_{2} \mathrm{HPO}_{4}$ and $\mathrm{Si}\left(\mathrm{C}_{2} \mathrm{H}_{5} \mathrm{O}\right)_{4}$ by sol-gel process. The sensor was fabricated with an alumina tube of $6 \mathrm{~mm}$ long, 0.8 and $1.2 \mathrm{~mm}$ in inner and outer diameters. The NASICON precursor was applied on an alumina tube twice and sintered at $900^{\circ} \mathrm{C}$ for $6 \mathrm{~h}$ in air. Then noble metal $(\mathrm{Pt}$ or $\mathrm{Au}$ ) and oxide layers were formed on the two ends of NASICON layer.

\section{Results and Discussion}

Table 1 shows some results of the NASICON based gas sensors using oxide electrodes. As shown in the table 1. For improving the performance of sensors, two main approaches have been utilized.

First, some novel oxide electrode materials for sensing $\mathrm{H}_{2} \mathrm{~S}, \mathrm{Cl}_{2}, \mathrm{SO}_{2}, \mathrm{NH}_{3}$ have been developed. For example, we have reported the NASICON based $\mathrm{H}_{2} \mathrm{~S}$ sensor using $\mathrm{Pr}_{6} \mathrm{O}_{11^{-}}$ doped $\mathrm{SnO}_{2}$ electrode as sensing electrode. It showed excellent sensing properties to $\mathrm{H}_{2} \mathrm{~S}$ at intermediate temperatures. The EMF value of the sensor was almost proportional to the logarithm of $\mathrm{H}_{2} \mathrm{~S}$ concentration, and the sensitivity(slope) was $74 \mathrm{mV} /$ decade at $300^{\circ} \mathrm{C}$ [10], as shown in Fig. 1.

The sensor using $\mathrm{CaMg}_{3}\left(\mathrm{SiO}_{3}\right)_{4}$-doped $\mathrm{CdS}$ sintered at $600{ }^{\circ} \mathrm{C}$ exhibited excellent sensing properties to 1-10 ppm chlorine in air at 100$250{ }^{\circ} \mathrm{C}$ [11]. Its sensitivity (slope) was 392 $\mathrm{mV} /$ decade at $200^{\circ} \mathrm{C}$. It also showed a good selectivity to $\mathrm{Cl}_{2}$ against $\mathrm{H}_{2} \mathrm{~S}, \mathrm{SO}_{2}, \mathrm{NO}_{2}, \mathrm{NH}_{3}$, $\mathrm{CH}_{4}$ and $\mathrm{CO}$, as shown in Fig. 2.

A high performance $\mathrm{SO}_{2}$ sensor was developed by combining NASICON with $\mathrm{V}_{2} \mathrm{O}_{5}$-doped $\mathrm{TiO}_{2}$ sensing electrode [12]. The sensor displayed excellent response and recovery characteristics to $1-50 \mathrm{ppm} \mathrm{SO}$ at $300{ }^{\circ} \mathrm{C}$, as shown in Fig. 3 . For increasing the sensitivity of the sensor to $\mathrm{NH}_{3}$, a porous $\mathrm{Cr}_{2} \mathrm{O}_{3}$ prepared by doping $\mathrm{C}$ was utilized as the sensing electrode [13]. As shown in Fig. 4, the sensor using porous $\mathrm{Cr}_{2} \mathrm{O}_{3}$ showed much higher sensitivity than that using
$\mathrm{Cr}_{2} \mathrm{O}_{3}$ particle. It can be attributted to the speedy diffusion through the porous sensing layer and lower loss of the $\mathrm{NH}_{3}$ concentration in the sensing layer.

Second, in order to improve the sensing performance and realize simple sensor array, we also focused on designing new device structures, such as the dual-function sensor using double oxide electrodes and the buried structure device for blocking the electrochemical reactions on the reference

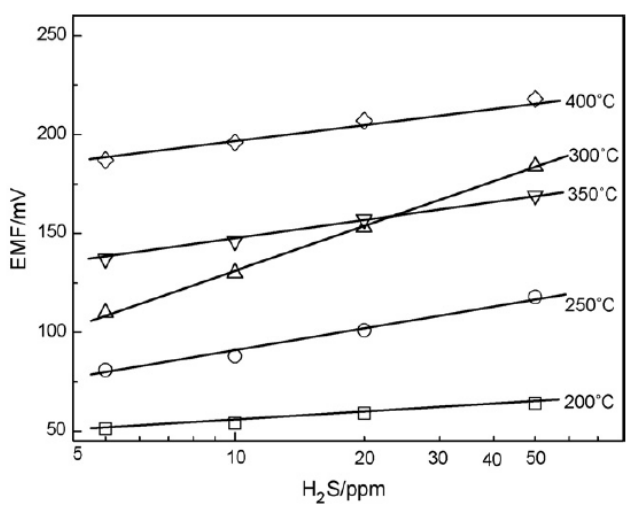

Fig. 1. Dependence of EMF of the sensor attached with $\mathrm{Pr}_{6} \mathrm{O}_{11}$-doped $\mathrm{SnO}_{2}$ on the $\mathrm{H}_{2} \mathrm{~S}$ concentration at $200-400^{\circ} \mathrm{C}$.

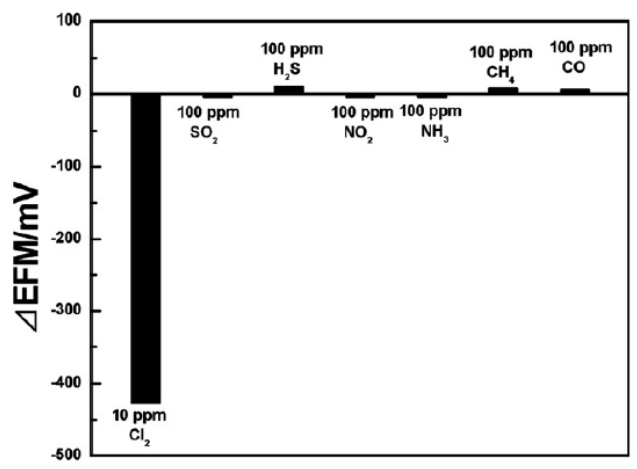

Fig. 2. Cross-EMF responses of the sensor using $\mathrm{CaMg}_{3}\left(\mathrm{SiO}_{3}\right)_{4}$-doped $\mathrm{CdS}$ to various gases at $200{ }^{\circ} \mathrm{C}$.

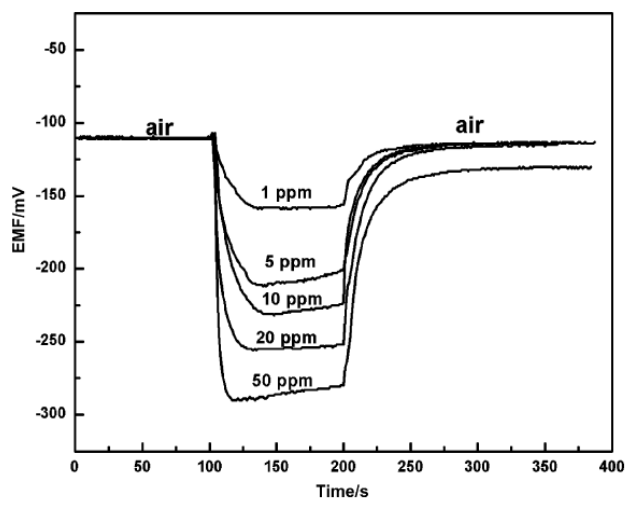

Fig. 3. Response transients of the sensor based on NASICON and $\mathrm{V}_{2} \mathrm{O}_{5}$-doped $\mathrm{TiO}_{2}$ sensing electrode to various concentrations of $\mathrm{SO}_{2}$ at $300^{\circ} \mathrm{C}$. 
Table 1 Typical examples of mixed-potential type gas sensors utilizing NASICON and different oxide electrodes

\begin{tabular}{|c|c|c|c|c|}
\hline Gas & $\begin{array}{c}\text { Sensor structure } \\
\text { Air, RE | electrolyte | SE, target gas }\end{array}$ & $\begin{array}{l}\text { Sensitivity ( } \\
\text { mV/decade ) }\end{array}$ & $\begin{array}{c}\text { Gas } \\
\text { conc. ( } \\
\text { ppm ) }\end{array}$ & $\begin{array}{c}\text { Operating } \\
\text { temperature } \\
\left({ }^{\circ} \mathrm{C}\right)\end{array}$ \\
\hline $\mathrm{H}_{2} \mathrm{~S}$ & Air, $\mathrm{Au}|\mathrm{NASICON}| \mathrm{Au}, \mathrm{Pr}_{6} \mathrm{O}_{11}-\mathrm{SnO}_{2}, \mathrm{H}_{2} \mathrm{~S}$ (+air) & 74 & $5-50$ & 300 \\
\hline $\mathrm{Cl}_{2}$ & Air, $\mathrm{Au}|\mathrm{NASICON}| \mathrm{Au}, \mathrm{Cd}_{3} \mathrm{O}_{2} \mathrm{SO}_{4}, \mathrm{Cl}_{2}$ (+air) & -392 & $1-10$ & 200 \\
\hline $\mathrm{SO}_{2}$ & Air, $\mathrm{Au}|\mathrm{NASICON}| \mathrm{Au}, \mathrm{V}_{2} \mathrm{O}_{5}-\mathrm{TiO}_{2}, \mathrm{SO}_{2}$ (+air) & -78 & $1-50$ & 300 \\
\hline $\mathrm{NH}_{3}$ & Air, $\mathrm{Au}|\mathrm{NASICON}| \mathrm{Au}$, porous $\mathrm{Cr}_{2} \mathrm{O}_{3}, \mathrm{NH}_{3}$ (+air) & -89 & $50-500$ & 350 \\
\hline $\mathrm{NO}_{2}$ & Air, $\mathrm{Pt}|\mathrm{NASICON}| \mathrm{Au}, \mathrm{NiO}, \mathrm{NO}_{2}$ (+air) & 78 & $5-200$ & 350 \\
\hline $\mathrm{CO}$ & Air, $\mathrm{Pt}|\mathrm{NASICON}| \mathrm{Au}, \mathrm{NiFe}_{2} \mathrm{O}_{4}, \mathrm{CO}$ (+air) & -45 & $100-1000$ & 350 \\
\hline $\mathrm{CO}$ & Air, $\mathrm{Au}|\mathrm{NASICON}| \mathrm{Au}, \mathrm{Y}_{2} \mathrm{O}_{3} \mathrm{CO}$ (+air) & -45 & $5-50$ & 400 \\
\hline $\mathrm{C}_{7} \mathrm{H}_{8}$ & Air, $\mathrm{Au}|\mathrm{NASICON}| \mathrm{Au}, \mathrm{Sm}_{2} \mathrm{O}_{3} \mathrm{C}_{7} \mathrm{H}_{8}$ (+air) & -75 & $5-50$ & 350 \\
\hline NO & Air, $\mathrm{Au}$ | NASICON | Au, $\mathrm{NiWO}_{4} \mathrm{CO}$ (+air) & 70 & $5-500$ & 350 \\
\hline $\begin{array}{l}\mathrm{NH}_{3} / \\
\mathrm{C}_{7} \mathrm{H}_{8}\end{array}$ & $\begin{array}{l}\mathrm{NH}_{3} \text { (+air ), } \mathrm{Cr}_{2} \mathrm{O}_{3}, \mathrm{Au},|\mathrm{NASICON}| \mathrm{Au}, \mathrm{Air}, \mathrm{Au} \mid \\
\mathrm{NASICON} \mid \mathrm{Au}, \mathrm{ZnO}-\mathrm{TiO}_{2}, \mathrm{C}_{7} \mathrm{H}_{8} \text { (+air) }\end{array}$ & $-91 /-60$ & $\begin{array}{c}50-500 \\
/ 5-50\end{array}$ & 350 \\
\hline $\mathrm{Cl}_{2}$ & Air, | NASICON | $\mathrm{Au}|\mathrm{NASICON}| \mathrm{Au}, \mathrm{Cr}_{2} \mathrm{O}_{3}, \mathrm{Cl}_{2}$ (+air) & -270 & $1-50$ & 300 \\
\hline
\end{tabular}

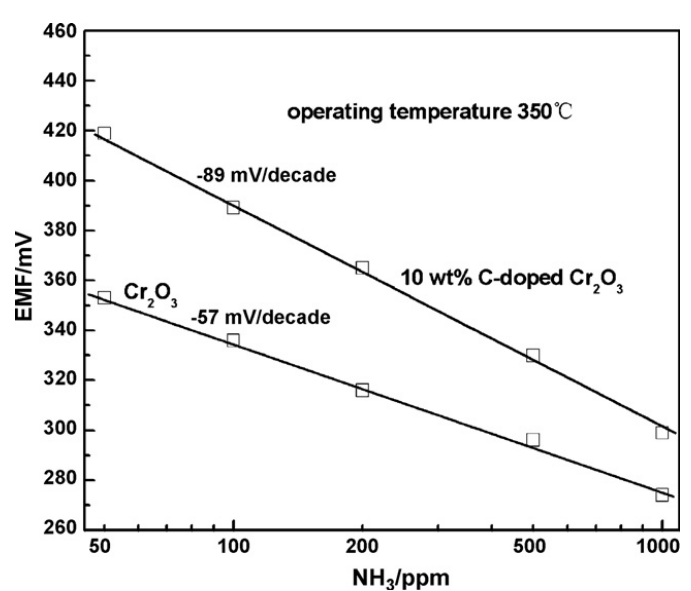

Fig. 4. Dependance of EMF on $\mathrm{NH}_{3}$ concentration for the sensor attached with the undoped $\mathrm{Cr}_{2} \mathrm{O}_{3}$ and the 10 wt\% C-doped $\mathrm{Cr}_{2} \mathrm{O}_{3}$.

electrode. Fig. 5 showed the structure as well as the response transients to different concentrations of $\mathrm{NH}_{3}$ and $\mathrm{C}_{7} \mathrm{H}_{8}$ for the dualfunction sensor using $\mathrm{Cr}_{2} \mathrm{O}_{3}$ and $\mathrm{ZnO}-\mathrm{TiO}_{2}$ at $350^{\circ} \mathrm{C}$. It can be seen that the electrode $\mathrm{A}$ showed higher response to $\mathrm{NH}_{3}$, but the electrode $\mathrm{B}$ displayed a higher response to $\mathrm{C}_{7} \mathrm{H}_{8}$. The combining of electrodes $A$ and $B$ can realize the simultaneous measurement to these two kinds of gases [14].

A buried structure sensing device was developed by using $\mathrm{Cr}_{2} \mathrm{O}_{3}$ electrode, which can effectively prevent the reaction of the target gas on reference electrode [15]. Fig.6 shows the dependence of $\triangle E M F$ on the $\mathrm{Cl}_{2}$ concentration for different type of sensor (type A: conventional device, type B: simple buried device and type C: deep-buried device), the sensitivity (-slope) for

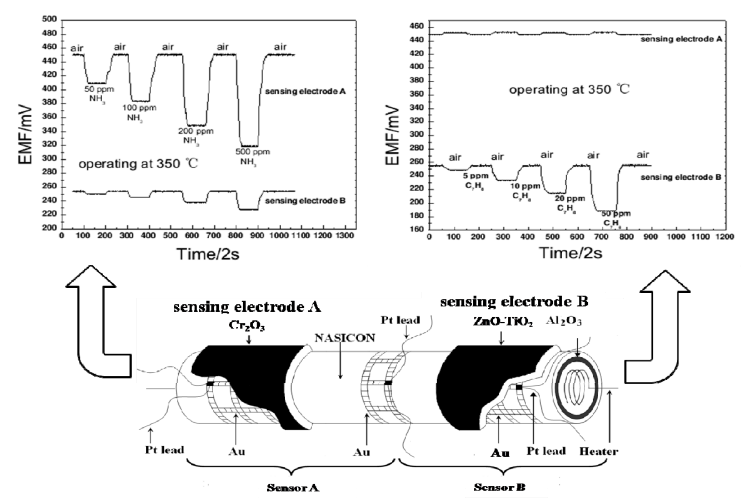

Fig. 5. Structure and response transients of dualfunction sensor using $\mathrm{Cr}_{2} \mathrm{O}_{3}$ and $\mathrm{ZnO}-\mathrm{TiO}_{2}$ for detection of $\mathrm{NH}_{3}$ and $\mathrm{C}_{7} \mathrm{H}_{8}$.

the type $\mathrm{C}$ was $-270 \mathrm{mV} /$ decade, which is much higher than those for type (A) (-119 $\mathrm{mV} /$ decade) and type (B) (-157 mV/decade).This suggested that covering reference electrode with NASICON in Type $\mathrm{B}$ and $\mathrm{C}$ can block the contact of $\mathrm{RE}$ with the $\mathrm{Cl}_{2}$ and restrain electrochemical reaction in the reference electrode. The potential difference between the sensing and reference electrode as well as the sensitivity of the sensor has been obviously increased. The other way to enhance the sensitivity is to increase the effective area of the sensing electrode. For the sensor $A$ and $B$, because the sensing electrode and reference electrode were located at both ends of the same NASICON layer, the area of the sensing electrode was reduced to about one half of the surface area of the first NASICON layer. However, for Type C, since the sensing electrode almost covers the all of the surface 
area of the second NASICON layer (Fig. 1 (C)), the area of the sensing electrode is greatly enlarged, and the sensitivity of the Type $C$ is obviously enhanced.

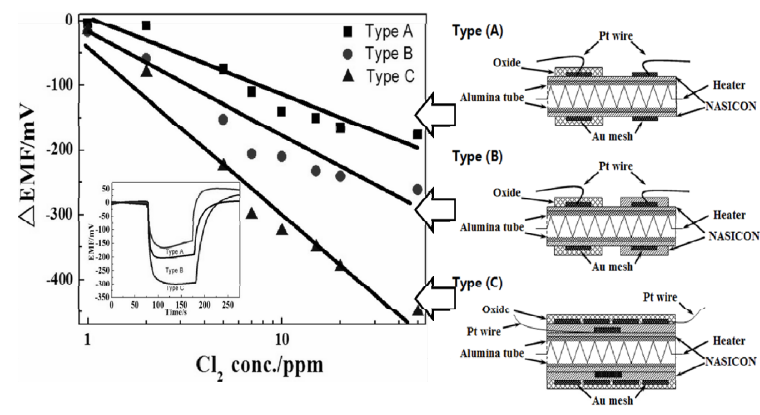

Fig. 6. The buried structure sensor using $\mathrm{Cr}_{2} \mathrm{O}_{3}$ for detection of $\mathrm{Cl}_{2}$

\section{Conclusions}

The mixed potential type sensors utilizing NASICON and oxide electrodes have been developed and showed a potential for detecting the harmful and toxic gases in the atmosphere.

\section{Acknowledgements}

Support by NSFC (Nos. 61074172, 61134010, 61104203) and Program for Chang jiang Scholars and Innovative Research Team in University (No. IRT1017) and Jilin province science and technology development plan program (20106002) is gratefully acknowledged.

\section{References}

[1] N. Barsan, M. Hübner, U. Weimar, Conduction mechanisms in $\mathrm{SnO}_{2}$ based polycrystalline thick film gas sensors exposed to $\mathrm{CO}$ and $\mathrm{H}_{2}$ in different oxygen backgrounds, Sensors and Actuators B 157, 510-517 (2011); doi:10.1016 /j.snb.2011.05.011.

[2] T. Miyata, T. Minami, Chlorine gas sensors with high sensitivity using Mg-phthalocyanine thin films, Applied Surface Science, 244, 563-567 (2005); doi: 10.1016/ j.apsusc.2004.10.120.

[3] S. Zhuiykov, N. Miura, Development of zirconiabased potentiometric $\mathrm{NO}_{x}$ sensors for automotive and energy industries in the early 21st century: What are the prospects for sensors? Sensors and Actuators B 121, 639-651 (2007); doi: 10.1016/j.snb.2006.03.044.

[4] M. Ono, K. Shimanoe, N. Miura, N. Yamazoe, Reaction analysis on sensing electrode of amperometric $\mathrm{NO}_{2}$ sensor based on sodium ion conductor by using chronopotentiometry, Sensors and Actuators B, 77, 78-83 (2001); doi:10.1016/S0925-4005(01) 00676-1.

[5] N. Miura, S. Yao, Y. Shimizu, N. Yamazoe, Highperformance solid-electrolyte carbon dioxide sensor with a binary carbonate electrode,
Sensors and Actuators B, 9, 165-170 (1992); doi:10.1016/0167-2738 (94) 90375 - 1 ,

[6] T. Kida, K. Shimanoe, N. Miura, N. Yamazoe, Stability of NASICON-based $\mathrm{CO}_{2}$ sensor under humid conditions at low temperature

, Sensors and Actuators B, 75, 179-187 (2001); doi:10.1016/S0925-4005(01) 00549-4,

[7] B.-K. Min, S.-D. Choi, $\mathrm{SO}_{2}$-sensing characteristics of Nasicon sensors with $\mathrm{Na}_{2} \mathrm{SO}_{4}$ $\mathrm{BaSO}_{4}$ auxiliary electrolytes, Sensors and Actuators B, 93, 209-213 (2003); doi:10.1016/ S0925-4005(03)00210-7.

[8] K. Obata, S. Matsushima, NASICON-based $\mathrm{NO}_{2}$ device attached with metal oxide and nitrite compound for the low temperature operation, Sensors and Actuators B, 130269-276 (2008); doi:10.1016/j.snb.2007.07.142.

[9] Y. Shimizu, N. Yamashita, Solid electrolyte $\mathrm{CO}_{2}$ sensor using NASICON and perovskite-type oxide electrode, Sensors and Actuators B, 64, 102-106 (2000); doi:10.1016/ S09254005(99)00491-8.

[10] X. Liang, Y. He, F. Liu, B. Wang, T. Zhong, B. Quan, G. Lu, Solid-state potentiometric $\mathrm{H}_{2} \mathrm{~S}$ sensor combining NASICON with $\mathrm{Pr}_{6} \mathrm{O}_{11}$-doped $\mathrm{SnO}_{2}$ electrode, Sensors and Actuators B, 125, 544-549 (2007); doi:10.1016/j.snb.2007.02.050.

[11] X. Liang, F. Liu, T. Zhong, B. Wang, B. Quan, G. $\mathrm{Lu}$, Chlorine sensor combining NASICON with $\mathrm{CaMg}_{3}\left(\mathrm{SiO}_{3}\right)_{4}$-doped CdS electrode, Solid State lonics, 179, 1636-1640 (2008); doi.org/10.1016/j.ssi.2008. 01.004.

[12] X. Liang, T. Zhong, B. Quan, B. Wang, H.Guan, Solid-state potentiometric $\mathrm{SO}_{2}$ sensor combining NASICON with $\mathrm{V}_{2} \mathrm{O}_{5}$-doped $\mathrm{TiO}_{2}$ electrode, Sensors and Actuators B, 134, 25-30 (2008); doi:10.1016/ j.snb.2008.04.003.

[13] Xishuang Liang, Tiegang Zhong, Hesong Guan, Fengmin Liu, Geyu Lu, Baofu Quan, Ammonia sensor based on NASICON and $\mathrm{Cr}_{2} \mathrm{O}_{3}$ electrode, Sensors and Actuators B 136, 479-483 (2009); doi:10.1016/j.snb.2008.11.028,

[14] X. Liang, G. Lu, T. Zhong, F. Liu, B. Quan, New type of ammonia/toluene sensor combining NASICON with a couple of oxide electrodes, Sensors and Actuators B, 150, 355-359 (2010); doi:10.1016/j.snb.2010.06.061.

[15] Zhang H., Liang X.; Li J., Lu G., NASICONBased Potentiometric $\mathrm{Cl}_{2}$ Sensor Combining NASICON with $\mathrm{Cr}_{2} \mathrm{O}_{3}$ Sensing Electrode, TRANSDUCERS 2011, 174 - 177(2011); doi:10.1109/TRANSDUCERS. 2011.5969253. 